University of California, Hastings College of the Law UC Hastings Scholarship Repository

Faculty Scholarship

2001

\title{
Water Rights for New Federal Land Conservation Programs: A Turn-of-the-Century Evaluation
}

John D. Leshy

UC Hastings College of the Law, leshyj@uchastings.edu

Follow this and additional works at: http://repository.uchastings.edu/faculty_scholarship

Part of the Natural Resources Law Commons, and the President/Executive Department Commons

\section{Recommended Citation}

John D. Leshy, Water Rights for New Federal Land Conservation Programs: A Turn-of-the-Century Evaluation, 4 U. Denv. Water L. Rev. 271 (2001).

Available at: http://repository.uchastings.edu/faculty_scholarship/384

This Article is brought to you for free and open access by UC Hastings Scholarship Repository. It has been accepted for inclusion in Faculty Scholarship by an authorized administrator of UC Hastings Scholarship Repository. For more information, please contact marcusc@uchastings.edu. 


\section{UNIVERSITY of CALIFORNIA HASTINGS COLLEGE OF THE LAW}

\section{Faculty Publications}

UC Hastings College of the Law Library

Author: John D. Leshy

Source: $\quad$ University of Denver Water Law Review

Citation: $\quad 4$ U. Denv. Water L. Rev. 271 (2001).

Title: Water Rights for New Federal Land Conservation Programs: A Turn-of-theCentury Evaluation

Originally published in UNIVERSITY OF DENVER WATER LAW REVIEW. This article is reprinted with permission from UNIVERSITY OF DENVER WATER LAW REVIEW and University of Denver Sturm College of Law. 


\title{
UNIVERSITY OF DENVER WATER LAW REVIEW
}

\section{WATER RIGHTS FOR NEW FEDERAL LAND CONSERVATION PROGRAMS: A TURN-OF-THE-CENTURY EVALUATION}

\author{
JOHN D. LESHY \\ ADAPTED FROM THE UNIVERSITY OF DENVER COLLEGE OF LAW \\ CARVER LECTURE \\ FEBRUARY 6, 2001
}

\section{Foreword by UNIVERSity OF DENVER COLLEge OF LAW Professor JAN G. LAITOS ${ }^{\ddagger}$}

John Leshy's Carver Lecture is published in this issue of the Water Law Review in an expanded form. The article is typical John Leshy scholarship-insightful, thoughtful, provocative, and useful. What his article on water rights for federal land conservation programs does not convey is the role John Leshy played in the creation of these programs. Therefore, a summary of the important position John Leshy held in the history of the Department of the Interior of the United States might be useful.

When Leshy became the Solicitor of the Interior Department in 1993, the Congress was split between Republicans and Democrats who could not seem to agree on natural resources programs. By 1994, when the Republicans gained control of the Congress, the United

\footnotetext{
'Professor of Law, Arizona State University (on leave); Solicitor, Department of the Interior, 1993-2001; Distinguished Visiting Professor of Law, Hastings College of the Law, 2001-2002. This article is a somewhat edited version of the Carver Lecture I delivered at the University of Denver, College of Law, on February 6, 2001. I appreciate the helpful comments of Professors Joseph Sax, Janet C. Neuman, and Michael C. Blumm on a draft version.

'John Carver, Jr. Professor of Law and Director, Natural Resources and Environmental Law Program, University of Denver College of Law.
} 
States government was further split between a Democratic President and a Republican House and Senate. The political situation remained fractionated until John Leshy left the federal government in 2001.

This political reality meant that, as a practical and realistic matter, it would likely be impossible for Secretary of the Interior, Bruce Babbitt, or his Solicitor, John Leshy, to have political initiatives successfully run the gauntlet through Congress and become signed by the President. New legislation would likely not be adopted during Leshy's tenure as Solicitor.

In fact, even though much federal environmental and natural resources legislation would have benefited from reauthorization by the Congress, virtually none was during the eight years that Leshy was Solicitor. The result was that not only did the Congress and the President fail to amend or revise existing federal lands laws, but few new laws involving public lands and resources received the blessings of the Executive and Legislative branches between the years 1992 and 2000. This meant that if Babbitt and Leshy were to impose any policy reform within the Interior Department, and on our public lands, they would have to do so in a way that did not need the formal approval of the Congress and the President.

And that is exactly what they did.

The real John Leshy legacy is that he and his boss, Bruce Babbitt, were able to bring about somewhat of a revolution in public lands and resources philosophy without the need of new or amended statutory authorization. John Leshy became the master of using his office, and the powers inherent in his office, to bring about change. He used Opinions of the Solicitor, new rules adopted under the Administrative Procedure Act, and administrative interpretations of existing laws to ensure that many Leshy and Babbitt policies were implemented during the eight years they served together in the Interior Department. Again, this implementation of their policies did not require new federal legislation. Although some may quarrel about the nature of, or even the benefits associated with, these policies, they certainly seemed consistent with the idea of conservation of scarce natural resources.

John Leshy's article on water rights for federal conservation programs discusses a change that occurred while he was Solicitor, but which, unlike some others, had the benefit of a specific congressional authorization, in the form of Great Sand Dunes National Park and Preserve Act. The Great Sand Dunes, along with other public lands, were set aside as a result of the far-thinking creativity of Leshy and Babbitt. Moreover, most of these public lands have some semblance of water that can be deployed to ensure their preservation long into the future.

The United States should look back one day in wonder at how an Interior Secretary and his Solicitor were able to bring about so many changes in our public lands policies, almost single-handedly (and certainly without explicit congressional approval). John Leshy showed how it can be done, for better or worse, but certainly with his signature 
firmly affixed to the product.

\section{FORMER SOLICITOR OF THE INTERIOR JOHN D. LESHY}

Background 274

Post -New Mexico Developments ......................................................2276

What's Wrong With Silence? ..............................................................2279

State Versus Federal Interests ...................................................282

A Third Way .......................................................................................285

Conclusion

My topic is how to integrate the water requirements associated with new federal land conservation initiatives - such as new national parks, wildlife refuges, conservation areas, recreation areas, and wilderness areas-with state water law systems. I am excluding any consideration of Indian water rights, because while they are closely linked conceptually with my topic, they are distinct enough-in contours, history, and equity - to require separate thinking. I am also excluding water needs to carry out federal regulatory programs such as the Clean Water Act or the Endangered Species Act.

How the national government should secure water rights for its federal land programs has been the subject of discussion for a long time. Just one piece of this large puzzle, the extent to which wilderness designations of federal land carry federal water rights with them, has led to a vigorous debate, waged in and out of courts for more than two decades. A lot of ink has been spilled on the subjectsome, I'll admit, by me ${ }^{1}$-yet the matter is still not finally settled. Just last year, voters threw off the bench an Idaho Supreme Court Justice after a spirited campaign in which the principal issue was the Justice's opinion, and her deciding vote in a court split 3-2, in favor of a federal reserved water right for national forest wilderness areas. After the Justice's defeat at the polls, but before she left the bench, another member of the court, the Chief Justice, switched her vote in the matter and the court reversed its decision. ${ }^{2}$

This episode was a sobering reminder of how a judiciary, subject to popular vote, may feel the sting of the backlash from a single decision. More pertinent to my topic here, it showed how much water rights issues-particularly those involving the federal government-still command great cultural and political value in the arid West. This was not, after all, a death penalty or abortion or election law case which

1. See, e.g., 86 Interior Decision 553, 609-10 (1979) (co-author); JOSEPH L. SAX ET AL., LEGAL CONTROL OF WATER RESOURCES 809-10 (3d ed. 2000); John D. Leshy, Water and Wilderness/Law and Politics, 23 LAND \& WATER L. REV. 389, 398-406 (1988).

2. Potlatch Corp. v. United States, 12 P.3d 1260 (Idaho 2000); see also, Rocky Barker, Water Ruling Reversed: Idaho High Court Decides Feds Don't Own Wilderness Flows but Reserve Control of 'Wild and Scenic' Salmon, IDAHO STATESMAN, Oct. 28, 2000, available at 2000 WL 28731552. 
can train public attention on the judiciary anywhere. But it illustrates what makes the disputatious West a lively venue for those of us interested in water law.

Congress had made the wilderness designations at issue in the Idaho case several decades ago, in 1964, 1978, and 1980. What I want to focus on here is not what has been done on this subject in the past, but on what Congress (or the executive, exercising power delegated to it by the Congress) might do in the future when they consider, as they surely will, setting aside more federal land for conservation purposes. What should they say, if anything, about securing water rights needed for such conservation set-asides from available, unappropriated water supplies? These last four words are important to bear in mind: I will assume throughout that water is available for these federal uses at the time Congress makes the new conservation designations. If the needed water is already subject to vested rights inconsistent with those uses, the federal government can secure water rights for new federal purposes only by purchase or donation.

\section{BACKGROUND}

Let me set the stage by first sketching out, in very broad strokes, how we got to where we are. To water aficionados, the story is familiar. Starting with the California Gold Rush in 1848, the issue of whether federal or state law would be paramount in allocating and administering water rights in the West was an abiding concern. Over the next century and a half, the underlying tension between national and state primacy was resolved by a series of expansions and contractions of state primacy. Those accordion-like movements took place every generation or so.

At first, the federal government basically got out of the way. The states and territories seized the initiative (or, more accurately, rushed into the vacuum left by federal inaction) to develop local laws and customs. The states mostly followed principles of prior appropriation, and applied these principles on, as well as off, federal lands. After almost two decades of silence, the federal government formally stepped aside in the Mining Acts of $1866^{3}$ and 1870 , $^{4}$ and the Desert Land Act of $1877,{ }^{5}$ deferring to local laws and customs to govern private parties' appropriation of water on federal lands. This made sense at the time, because the federal government wasn't really thinking about conserving land for national purposes, with one notable exception: Yellowstone. ${ }^{6}$

Toward the end of the nineteenth century, however, the national

3. Act of July 26,1866 , ch. $262, \S 9,14$ Stat. 251 , 253. See generally SAX ET AL., supra note 1 , at $287-89$.

4. Act of July 9, 1870, ch. 235, $\S 17,16$ Stat. 217, 218. 306.

5. Act of Mar. 3, 1877, ch. 107, § 1, 19 Stat. 377. See SAX ET Al., supra note 1, at

6. Act of Mar. 1, 1872, ch. 24,17 Stat. 32 (codified as amended at 16 U.S.C. $\S 21$ (1994)). 
government began, in earnest, to reserve large tracts of federal land from disposition, and concomitantly began to reassert some control over western water resources. In its 1899 Rio Grande decision, the U.S. Supreme Court made clear that the federal government had the right, "as the owner of lands bordering on a stream, to [command] the continued flow of its waters; so far at least as may be necessary for the beneficial uses of the government property. ${ }^{n 7}$ Less than a decade later, the Supreme Court developed this idea into a black letter principle of federal law. In the famous Winters case, it held that when the United States reserved land for national purposes-in that case, for an Indian reservation-and was silent on water, it also implicitly reserved enough available water (i.e., which had not already been spoken for under federal or state law) to carry out those purposes. ${ }^{8}$

Twenty-seven years after Winters, the pendulum swung back. In its 1935 California Oregon Power decision, ${ }^{9}$ the Court interpreted the 1866, 1870 , and 1877 statutes as "severing" water from land in the West, at least for purposes of private appropriation. While the Court's opinion did not address Winters (though it did discuss Rio Grande), its emphasis on the "public interest in ... state control in the arid-land states" left an impression that the Court was not going to expansively interpret the "implied-federal-reserved-water-rights" doctrine.

Another generation, another swing of the pendulum. In 1955, in its so-called Pelton Dam decision, the Court strongly hinted that federal reservations of land outside the Indian context also carry Winters' rights with them, by holding that California Oregon Power's severance doctrine did not apply to reserved federal lands. ${ }^{\text {In }}$ 1963, the Court confirmed this result, almost as an afterthought, in the landmark decision Arizona v. Califormia. ${ }^{12}$

The application of the Winters principle to reservations of federal land for other than non-Indian purposes troubled the states, who already didn't think much of Winters in the Indian context. By the time the Court decided Arizona v. Califormia, the national government had set aside upwards of two hundred million acres of federal land as national parks, forests, wildlife refuges, and other protected categories. Almost none of these reservations specifically mentioned water, but Arizona $v$. California seemed to say all of them silently reserved water.

Perhaps reflecting the quickening population and economic growth in the West, the next pendulum swing took less than a generation. In the 1976 Devil's Hole pupfish case, ${ }^{, 3}$ the Court signaled a limit as to how far it would go to find a water right implied from silence. The decision itself dramatically asserted federal supremacy,

7. United States v. Rio Grande Dam \& Irrigation Co., 174 U.S. 690, 703 (1899).

8. Winters v. United States, 207 U.S. 564 (1908).

9. Cal. Or. Power Co. v. Beaver Portland Cement Co., 295 U.S. 142 (1935).

10. Id. at 165.

11. Fed. Power Comm'n v. Oregon, 349 U.S. 435, 448 (1955).

12. Arizona v. California, 373 U.S. 546, 601 (1963).

13. Cappaert v. United States, 426 U.S. 128 (1976). 
because the Court applied federal law to shut down groundwater pumping authorized under state law on private land in order to protect an underground pool found on federal land more than two miles away. The pool was included in a national monument President Truman established in 1952, under the Antiquities Act of $1906,{ }^{14}$ in order to protect the habitat of a rare fish. But the Court seemed to go out of its way to say that President Truman had expressly, not impliedly, reserved water in the proclamation. And then it said, ominously for pro-federal interests, that water reserved by the "implied-reservation-of-water-rights doctrine" was "only that amount of water necessary to fulfill the purpose of the reservation, no more." ${ }^{.15}$

Cappaert laid the groundwork for the New Mexico decision two years later. ${ }^{16}$ There the Court handed federal land managers a major setback by finding that water had not been implicitly reserved for wildlife, recreation or other such uses when Congress established the Gila National Forest in New Mexico at the end of the previous century. Instead, the reservation was only for the primary purposes of timber supply and "favorable [conditions of] water flows" (whatever the latter might mean), but not for "secondary use[s]" of the reservation, like wildlife and recreation. ${ }^{17}$ This distinction between principal purposes and secondary uses appeared for the first time in this case-seventy years after Winters.

\section{POST-NEW MEXICO DEVELOPMENTS}

In the twenty-three years since New Mexico, the century-old practice of setting aside federal land for various conservation purposes has continued apace. Congress has done it in numerous statutes, and the Executive-especially Presidents Carter and Clinton-has done it by exercising authority delegated by Congress under the Antiquities Act.

In these more recent actions, a rather remarkable, but mostly unremarked-upon, thing has happened. As explained further below, most of these acts have specifically addressed water rights. The trend is moving away from the traditional approach of silence ${ }^{18}$ - that is, not expressly saying whether water was or was not reserved. The trend line is not unbroken; Congress enacted legislation last year establishing national conservation areas east of Tucson and north of Reno, a national monument near Palm Springs, and protections for the Steens Mountain in Oregon, all of which were silent on whether water was

14. 16 U.S.C. $\$ \S 431-433$ (1994).

15. Cappaert, 426 U.S. at 141.

16. United States v. New Mexico, 438 U.S. 696 (1978).

17. Id. at $700,702,716$.

18. What I call silence includes situations where Congress (or the Executive) says something about water, but what it says is not very meaningful. Typical of these disclaimers is the one found in the Wilderness Act: "Nothing in this [act] shall constitute an express or implied claim or denial on the part of the Federal Government as to exemption from State water laws." 16 U.S.C. $\$ 1133(\mathrm{~d})(6)$ (1994) (emphasis added). 
reserved. $^{19}$

This brings up another remarkable, and also mostly unremarkedupon, development. While the federal government now often explicitly addresses water, there is no consistent pattern in what it has said. For example, 1984 and 1990 legislation designating federal lands in Arizona as wilderness, 1987 legislation establishing a national monument, national conservation area, and wilderness on federal land in New Mexico, 1988 legislation establishing national park wilderness in the state of Washington and a national riparian conservation area in Arizona, 1990 legislation establishing national conservation areas in Nevada and Arizona, and 1994 legislation establishing conservation units in the California Desert, all explicitly reserved water for these purposes as a matter of federal law. ${ }^{20}$ By contrast, 1988 legislation establishing national monuments in Idaho and 2000 legislation establishing a national conservation area and a wilderness area in Colorado expressly disclaimed any reservation of water under federal law. ${ }^{21} \quad$ There is also the occasional oddball provision that does neither. ${ }^{22}$

Those crafting legislation often find that silence is a convenient way to paper over differences on a difficult or controversial aspect of the proposal under consideration. But in the context of new federal land conservation legislation, silence on water is now sometimes resisted so much that, if the pertinent interest groups cannot come to agreement about how water will be addressed, the result may be no legislation at all. For instance, a stalemate over whether Congress would reserve water held up Colorado wilderness legislation for nearly a decade. The impasse broke in 1992-93 only after intensive

19. Las Cienegas National Conservation Area Act of 2000, Pub. L. No. 106-538, 114 Stat. 2563 (Arizona); Black Rock Desert-High Rock Canyon Emigrant Trails National Conservation Area Act of 2000, Pub. L. No. 106-554, 114 Stat. 2763 (Nevada); Santa Rosa and San Jacinto Mountains National Monument Act of 2000, Pub. L. No. 106351, 114 Stat. 1362 (California); Steens Mountain Cooperative Management and Protection Act of 2000, Pub. L. No. 106-399, 114 Stat. 1655 (Oregon).

20. See 16 U.S.C. § 460uu-49 (1994) (El Malpais National Monument and Conservation Area, New Mexico); 16 U.S.C. $\$ 460 x x-1$ (d) (1994) (San Pedro Riparian National Conservation Area, Arizona); 16 U.S.C. $\$ 460 \mathrm{ccc}-8$ (1994) (Red Rock Canyon National Conservation Area, Nevada); 16 U.S.C. $\$ 460$ ddd(f) (Gila Box Riparian National Conservation Area, Arizona); see also SAX ET AL., supra note 1, at 812-13.

21. See 16 U.S.C. $\$ 460 y y-1$ (f) (1994) (City of Rocks National Reserve, Idaho); Colorado Canyons National Conservation Area and Black Ridge Canyons Wilderness Act of 2000, Pub. L. No. 106-353, § 6(1) (2), 114 Stat. 1374, 1378.

22. See 16 U.S.C. $\$ 46011-3(d)$ (1994), which provided that nothing in the 1980 legislation establishing the Rattlesnake National Recreation Area in Montana "shall be construed to permit the [federal land managing agency] to affect or diminish any water right which is vested under either State or Federal law on October 19, 1980," nor affect access by the owner of any such water right to operate and maintain any water facilities. See also 16 U.S.C. $\$ 460$ iii-5(d) (1994) (Snake River Birds of Prey National Conservation Area, Idaho) (no need for additional reservation of water because United States already claiming prior water rights for conservation purposes in ongoing general stream adjudication); 16 U.S.C. $\$ 543 \mathrm{c}$ (b) (1994) (Mono Basin National Forest Scenic Area, California) (area to be managed consistent with protection of established water rights). 
negotiations produced agreement that, while the legislation would expressly not reserve water, it would contain an elaborately defined alternative way to protect the water resources of the high altitude wilderness areas-through controls on access by the federal land manager. ${ }^{23}$

The Carter and Clinton Administrations also generally opted against silence when they exercised executive authority to reserve federal land for conservation purposes. President Carter's seventeen Alaska national monuments (covering fifty-six million acres of federal land) expressly reserved water. ${ }^{24}$ Almost all of President Clinton's nearly two dozen national monument proclamations addressed water, though not in a uniform way. Water was expressly reserved to carry out the purposes of the Agua Fria National Monument north of Phoenix ${ }^{25}$ the Cascade Siskiyou in southern Oregon, ${ }^{26}$ the Sequoia in California, ${ }^{27}$ and the enlargement of the Pinnacles National Monument in California. ${ }^{28}$ A reservation of water was expressly disclaimed in the Grand Staircase-Escalante National Monument, ${ }^{29}$ the Grand Canyon-Parashant, ${ }^{\text {so }}$ Vermilion Cliffs, ${ }^{31}$ Canyons of the Ancients, ${ }^{32}$ Ironwood Forest, ${ }^{33}$ Sonoran Desert, ${ }^{34}$ and in the enlargement of the Craters of the Moon. ${ }^{35}$ The Missouri Breaks and

23. See Colorado Wilderness Act of 1993, Pub. L. No. 103-77, §8, 107 Stat. 756, 76263; SAX ET AL., supra note 1, at 813-14. Specifically authorizing control of access to federal lands to protect water avoids the controversy that sometimes accompanies federal land managers using their ordinary authority over access to the same end. See Janet C. Neuman \& Michael C. Blumm, Water for National Forests: the Bypass Flow Report and the Great Divide in Western Water Law, 18 STAN. ENVTL. L.J. 3 (1999).

24. See, e.g., 43 Fed. Reg. 57,035, 57,036 (Dec. 5, 1978) (Denali National Monument) ("There is also reserved all water necessary to the proper care and management of those objects protected by this monument and for the proper administration of the monument in accordance with applicable laws.").

25. Proclamation No. 7263, 65 Fed. Reg. 2817, 2818 (Jan. 11, 2000) (Agua Fria National Monument).

26. Proclamation No. 7318, 65 Fed. Reg. 37,249, 37,250 (June 13, 2000) (CascadeSiskiyou National Monument).

27. Proclamation No. 7295, 65 Fed. Reg. 24,095, 24,098 (Apr. 25, 2000) (Giant Sequoia National Monument).

28. Proclamation No. 7266, 65 Fed. Reg. 2831, 2832 (Jan. 18, 2000) (Boundary Enlargement of the Pinnacles National Monument).

29. Proclamation No. 6920, 61 Fed. Reg. 50,223, 50,225 (Sept. 24, 1996) (Establishment of the Grand Staircase-Escalante National Monument).

30. Proclamation No. 7265, 65 Fed. Reg. 2825, 2828 (Jan. 18, 2000) (Establishment of the Grand Canyon-Parashant National Monument).

31. Proclamation No. 7374, 65 Fed. Reg. 69,227, 69,229 (Nov. 15, 2000) (Vermilion Cliffs National Monument).

32. Proclamation No. 7317, 65 Fed. Reg. 37,243, 37,245 (June 13, 2000)

(Establishment of the Canyons of the Ancients National Monument).

33. Proclamation No. 7320,65 Fed. Reg. 37,259, 37,260 (June 13, 2000) (Establishment of the Ironwood Forest National Monument).

34. Proclamation No. 7397, 66 Fed. Reg. 7354, 7356 (Jan. 22, 2001) (Establishment of the Sonoran Desert National Monument).

35. Proclamation No. 7373, 65 Fed. Reg. 69,221, 69,223 (Nov. 15, 2000) (Boundary Enlargement of the Craters of the Moon National Monument). These proclamations (notes 29-35) typically instructed the federal land manager to cooperate with state 
Hanford Reach proclamations took a middle course: in Missouri Breaks, water was expressly reserved only in two tributaries with outstanding cottonwood gallery forests; ${ }^{36}$ and at Hanford, water was expressly reserved only in the main stem of the Columbia, but not in tributaries. $^{37}$

In each case, the President accepted Secretary Babbitt's recommendation regarding water, which was based on the Secretary's judgment about whether a reservation of water was necessary to protect the monument's purposes. As one deeply involved in this process, I can attest that we looked at what the monument's needs for water were; whether the necessary water resources were already protected by other, previous federal reservations; and whether any additional protection that might be advisable could be afforded other ways (such as through land access controls). We also assessed the risk that new water rights might be perfected under state law outside the monument that could interfere with monument purposes.

\section{WHAT'S WRONG WITH SIILENCE?}

The trend away from silence in the last twenty years has been a sea change, a departure from well over a century of traditional practice. It is worth pausing to explore why this has happened. One reason is that conservation opponents have seized upon this issue as a useful way to resist conservation designations. Many traditional water developers and their allies believe a demand that water be addressed will mean either that water won't be reserved, or better yet (in the eyes of some), conservation designations won't be made at all.

But there is more to it than this. Opponents of silence also make a more principled argument, that silence simply leaves too much uncertain. There may exist a wide gulf between what the federal government claims as a water right from silence under the impliedreservation-of-water doctrine, and what other interests, claiming rights under state law, are willing to acknowledge. Until a binding adjudication occurs, no one knows whether, or how much, water is being reserved. The uncertainty may continue for decades. While the McCarran Amendment ${ }^{38}$ gives the states first crack at figuring out what silence means (if they want to go to the trouble of conducting general stream adjudications), a long time may pass before litigation is instituted, and even longer before it is brought to the point of decision. ${ }^{39}$ Almost eighty years went by before the U.S. Supreme Court

water authorities to secure needed water rights.

36. Proclamation No. 7398, 66 Fed. Reg. 7359, 7361 (Jan. 22, 2001) (Establishment of the Upper Missouri River Breaks National Monument).

37. Proclamation No. 7319, 65 Fed. Reg. 37,253, 37,255 (June 13, 2000)

(Establishment of the Hanford Reach National Monument).

38. 43 U.S.C. $\$ 666$ (a) (1994); see SAX ET AL., supra note 1, at 815-29.

39. Note, however, that this is not so much of a problem with new land reservations in Colorado because of Colorado's unique system of continuous or rolling adjudications of water rights, including those based on federal law. See, e.g., United States v. Dist. Ct. for Eagle County, 401 U.S. 520, 522-23 (1971). 
interpreted the silence of an 1899 forest reservation in United States $v$. New Mexico. ${ }^{40}$ Thirty-six years elapsed before the Idaho Supreme Court decided what a 1964 wilderness designation meant for water rights. ${ }^{41}$

Moreover, punting to the courts to decide the matter at some future time is playing a form of roulette with the outcome, given the historical shifts of the Supreme Court on the subject recounted earlier. It is difficult to predict how the courts will decide, or when they will decide, what silence means in the numerous federal reservations. The decision depends, at least in part, on when and in what form the issue is taken to the courts, and who is sitting on the bench.

It is also worth noting that even when Congress or the Executive expressly reserves water, neither typically identifies a specific amount. While the fact that Congress reserves water for specified purposes is no longer open to dispute in such legislation, the amount of water necessary to carry out the purposes may be vigorously disputed. Adjudication is necessary to settle the matter. Therefore, even an express reservation of water leaves important issues open, perhaps for a long time.

Opponents of federal reservations of water usually put forward arguments against silence in new federal reservations. However, the uncertainty created by silence (or left even by an express but unquantified reservation of water, as pointed out in the preceding paragraph) is potentially harmful to federal interests as well. The United States usually lacks sufficient incentive to identify and quantify its claims until it is compelled to do so when joined in a state general stream adjudication. In the meantime, uncertainty may lead the federal land managing agency not to act vigilantly in protecting its inchoate federal water right claims against encroachment by later appropriators. This can make the assertion and defense of federal water rights harder, in a practical and political if not a legal sense, when an adjudication of those rights is finally at hand. Furthermore, if the courts eventually decide that silence in a particular reservation does not reserve water for some federal purposes, the federal government will at that point have lost potentially valuable years of priority, if it then takes what may be the only practicable course left: file an application to appropriate the needed water under state law. (The practice of the United States has been not to file under state law for water that it believes it has already reserved under the reserved rights doctrine, for fear that filing for the former will undermine its claim to the latter once the matter goes to adjudication.) Assuming the United States could have appropriated water under New Mexico law for wildlife or recreational flows when Congress created the Gila

40. United States v. New Mexico, 438 U.S. 696 (1978).

41. Potlatch Corp. v. United States, 12 P.3d 1260 (Idaho 2000). The Idaho Supreme Court provided another example earlier this year when, in a questionable decision, it determined that a 1937 reservation of the Deer Flat Migratory Waterfowl Refuge on some islands in the Snake River did not implicitly reserve water to maintain the character of the islands as a refuge from predators. United States v. State, 2001 WL 170644 (Idaho Feb. 22, 2001). 
National Forest in $1899,{ }^{42}$ the fact that the Supreme Court took seventy-nine years to decide, in United States v. New Mexico, that the reservation did not include an implied federal reserved water right for these purposes was costly. The difference of priority might well determine whether water is available to be appropriated to serve the federal purposes.

Although I have suggested reasons why silence can threaten all sides, the problems silence causes may be larger in theory than in fact. It is true that nearly all the major land reservation systems in the west-national forests, national parks, etc.-were created without specifically addressing water. And it is also true that many of the implied federal reserved water rights that may attach to these hundreds of millions of acres of federal land have not yet been finally, definitively settled. Yet this uncertainty has had no demonstrable negative impact on economic activity in the region. By almost every conventional measure-such as population and economic growththe West has plainly thrived for many decades amidst uncertainty over the scope of federal claims to water. Whether silence has had a negative effect on the federal government's ability to secure water for conservation purposes is more difficult to assess. ${ }^{43}$ The U.S. Forest Service will have a more difficult time securing recreational and environmental flows for national forests because of how the U.S. Supreme Court interpreted silence in the New Mexico case, and securing wilderness flows because of how the Idaho Supreme Court interpreted silence in the recent Idaho case. But whether federal programs will be thwarted as a result is harder to say. It is possible, then, that silence has not proved crippling. But the uncertainty silence breeds is at least annoying, and at worst has the potential to adversely affect both federal and state water interests.

Although opinions may differ on whether silence ought to remain acceptable, the political reality is that those with power to make new designations in the executive and legislative branches generally believe silence is unacceptable. This reality alone makes silence less likely in the making of new federal land conservation designations than it was a generation ago. The effect may be to postpone the land conservation actions, or to go ahead with the designation but expressly not reserve water. The latter leaves the United States wholly dependent on state law and, as I will explain in a moment, at the mercy of state forces, who lack a structural check against the tendency to act hostile to federal interests.

Nevertheless, as noted above, some new federal land conservation legislation has remained silent on water. This move away from silence

42. Admittedly, this a dubious assumption because even today New Mexico law sharply limits instream flow appropriations, if indeed it allows them at all. See SAX ET AL., supra note 1 , at 114-15.

43. Probably silence has had a negative impact on securing water for Indians, but that question is beyond my compass here. Cf. Nevada v. United States, 463 U.S. 110 (1983). 
leaves an interesting question: when Congress enacts some land conservation bills that expressly disclaim any reservation of water, and others that expressly reserve water, what does a bill that is silent on the subject mean to say about the matter? Can one draw an inference that silence means water is reserved, or that it is not reserved, or is silence merely neutral? The answer is not clear, but it is entirely possible that a court not very moved by claims on behalf of the environment, which is a fair characterization of the current Supreme Court, will find silence today means no federal reservation of water. This suggests, in turn, that environmental advocates, who want to maximize federal reservations of water for environmental purposes, face an increasingly uphill fight in convincing the courts that silence now means-as it once did, in the era of the Winters - that water is reserved as a matter of federal law. ${ }^{44}$

This puts pro-conservation interests on the horns of a dilemma. On the one hand, pro-conservationists may accept silence now only to see, twenty or fifty years from now, the courts decide that today's silence does not reserve water. This would mean, as pointed out above, that the federal government will have lost twenty or fifty years of priority if it then files under state law to appropriate the water it needs. In the worst case, no more unappropriated water may exist. On the other hand, environmental interests may oppose an otherwise proconservation designation because they decide they can't accept silence on water or, worse, an express decision not to reserve water as a matter of federal law. In such a situation, if silence or an express disclaimer that no water is reserved is the only way to secure enough political support to take the action, the result would be that the proconservation designation does not go forward. Where this dilemma exists, in other words, environmentalists must decide whether they should (a) support pro-conservation actions without assurance that water will be protected as a matter of federal law; or instead (b) accept a delay in achieving protection, and hope that the national government will eventually find a way to protect whatever water is then available for the federal purposes as a matter of federal (or possibly state) law.

\section{STATE VERSUS FEDERAL INTERESTS}

At this point, it may be useful to take a step back, to examine the broader question of what federal and state interests are really at stake in this debate. This will prepare the ground for exploring whether there is an approach that might, at least in some circumstances, better reconcile those interests. The states have a sovereign interest in having their laws control water rights administration as much as

44. Pro-reservation advocates are not without arguments. For example, they can focus more on the necessity of water to the reservation purpose rather than any implied intent to reserve. They can also argue that legislative silence simply reflected a determination to leave the matter to the courts, rather than being a congressional decision not to reserve water. 
possible. They also perceive an economic interest in controlling water through state law. This economic interest exists partly because, in my experience at least, the states tend to favor traditional uses of water for what might be called commodity purposes-agricultural irrigation and municipal and industrial uses. Finally, the states also have a general interest in securing notice of federal as well as other water claims, and certainty about what those claims are. On its side, the federal government has a general interest in securing water (including, where appropriate, perfecting property rights in water) to meet the needs of federal programs, especially environmentally related programs, as easily and cheaply as possible.

States'-righters argue that complete deference to state water law systems will work just fine to meet federal needs. Both history and political science suggest the contrary, however. Powerful forces pull states away from responding to federal needs, even when unappropriated water is available. As a broad generalization, state water administration systems in the West tend to be at least somewhat captive of traditional interests; that is, no long and strong tradition of independent-mindedness exists among state water bureaucracies. Moreover, some state substantive laws simply do not adequately recognize water rights (e.g., instream flows, or rights that protect surface water from groundwater diversions) that may be necessary to protect federal interests, and they may not permit federal agencies to hold such rights. ${ }^{45}$ While state governing bodies (including state courts) have generally become more progressive on water issues in the last couple of decades, they still have a considerable distance to travel before one can depend on them to recognize, let alone safeguard, the needs of federal land conservation systems wholly through state law. ${ }^{46}$

States may never get there, for they have powerful internal incentives to let parochial, anti-federal interests win out. In addition to the backlash against the Idaho Supreme Court decision described above, this was illustrated in 1995 when both Arizona and Nevada amended their state laws in response to ranching interests. Both states prohibited the federal Bureau of Land Management ("BLM"), and Arizona additionally prohibited the U.S. Forest Service, from applying for water rights for livestock grazing on federal lands. These new laws applied only to the federal agencies, and not to state land management agencies. They altered, only for federal lands, the traditional rule in both states that allowed the landowner, not the livestock owner, to hold the water rights associated with livestock

45. See, e.g., Jack Sterne, Instream Rights E Invisible Hands: Prospects for Private Instream Water Rights in the Northwest, 27 ENVTL. L. 203 (1997).

46. For a thoughtful general review of the disappointing efforts to reform state water policy in the $1990 \mathrm{~s}$, see David H. Getches, The Metamorphosis of Western Water Policy: Have Federal Laws and Local Decisions Eclipsed the States' Role? 20 STAN. ENVTL. L.J. 3, 71 (2001) ("Although the reasons for reform persist and are better understood than ever, existing state legal and institutional frameworks endure virtually unchanged. Vocal interests with expectations or vested rights rooted in old policies typically resist proposals to ... dedicate more water to instream uses."). 
grazing. ${ }^{47}$ While the issue was not on its face a dispute over environmental conservation, in reality it was: the livestock interests in the states wanted water rights associated with public land livestock grazing exclusively in their own names, not in the names of government agencies. The purpose was both symbolic and practicalto make it harder for the federal agencies to restrict or reduce livestock grazing on public lands for environmental protection or restoration purposes.

Livestock graziers compose a tiny part of each state's economy. Nearly all other water interests in each state are indifferent to the matter. Yet regarding this issue, the state legislatures easily adopted laws that blatantly discriminated against federal land managers. This behavior neatly illustrates the ineluctable fact that, while state interests are well represented in the operations of the national government, the contrary is not so true. ${ }^{49}$ When the states are found in the arid West and the subject matter is water, the difficulty state governments have in accounting for federal government interests is even more pronounced.

These facts do not lead to the conclusion that the federal government should seek to minimize involvement with state water rights systems, even if it had that luxury (which it does not). On the contrary, the federal government's long-term interest is to work through and help build up the quality of state water rights administration. This goal recognizes several enduring realities. First, state systems are the primary force in the field-there is not, and likely never will be, a general federal water law or water rights administrative system that parallels that of the states. Second, the McCarran Amendment, which basically gives the states the option to adjudicate and administer federal reserved water rights in state systems along with their own state law water rights, is very unlikely to be repealed in the foreseeable future. Third, federal reserved water rights have never been, and will never be, the only way the federal government secures water needed for federal purposes. The Bureau of Reclamation and the Bureau of Land Management are primarily dependent on state law to meet the water needs of their programs. Even federal agencies like the U.S. Forest Service (particularly after New Mexico) and the U.S. Fish and Wildlife Service also rely on state law for at least some of their water needs.

For all these reasons, the more competent, professional, and impartial the state systems are, the better for the federal government. But simply improving the quality of state systems cannot solve the structural problem-the built-in temptation to favor local interests

47. See SAX ET AL., supra note 1, at 871-72.

48. See, e.g., Hage v. United States, 42 Fed. Cl. 249 (1998); Mitchell v. United States, 41 Fed. Cl. 617 (1998); Store Safe Redlands Assocs. v. United States, 35 Fed. Cl. 726 (1996).

49. Cf. Herbert Wechsler, The Political Safeguards of Federalism: The Role of the States in the Composition and Selection of the National Government, 54 COLUM. L. REV. 543 (1954).

50. See SAX ET AL., supra note 1, at 866-72. 
over federal ones. This situation suggests the need to retain a counterbalancing dose of federal law. ${ }^{\text {. }}$ The need for a federal counterweight is particularly true in making new federal conservation designations, for this is where state water law may be the weakest compared to what would obtain under the federal reserved rights doctrine. It is rather difficult to imagine, for example, that a state agency or court would have applied state law to reach the same result the Supreme Court reached in the Devil's Hole pupfish case-to find a water right to protect an obscure fish of no commercial value (albeit of significant scientific interest) when such protection required shutting down a farmer's wellfield. ${ }^{52}$

\section{A THIRD WaY}

Which brings me, finally, to the question of whether there might be another way, when Congress considers new federal land conservation programs, to integrate associated federal water needs with state water law systems. At least in some circumstances, the answer may be yes. Legislation recently adopted regarding the Great Sand Dunes in Colorado, legislation strongly supported by most of Colorado's congressional delegation and the Clinton Administration, is worth examining. ${ }^{53}$ Its approach did not conform to the traditional dichotomy between state water rights and federal reserved water rights. It holds some promise for breaking out of that box in a way that accommodates both federal and state interests.

Proposals to export water from the San Luis Valley to Colorado's burgeoning Front Range had created controversy in recent years. ${ }^{54}$ Last year, export opponents joined forces with conservationists who wanted to see the Great Sand Dunes National Monument ${ }^{55}$ expanded yet again $^{56}$ to encompass all of the natural features now understood, given advances in scientific knowledge, as necessary for the preservation of the Dunes ecosystem. (Those natural features, not incidentally, include surface and groundwater resources upon which

51. Professor Getches persuasively explains how many of the more progressive reforms in state water management in the last decade have come about because of federal pressure. See Getches, supra note 46, at 42-59.

52. In Cappaert, the National Park Service asked the Nevada State Engineer either to deny or delay a decision on Cappaert's application to install a wellfield until the completion of a Park Service commissioned hydrologic study to assess the proposed wellfield's impact on the national monument and the pupfish habitat. The State Engineer brushed the request aside, finding the grasses and grains Cappaert wanted to grow with well water better served the public interest than doing the study. See Cappaert v. United States, 426 U.S. 128, 134-35 (1976).

53. Great Sand Dunes National Park and Preserve Act of 2000, Pub. L. No. 106-530, 114 Stat. 2527.

54. See, e.g., Am. Water Dev., Inc. v. City of Alamosa, 874 P.2d 352 (Colo. 1994).

55. President Hoover first created the Great Sand Dunes National Monument in 1932. See Act of Mar. 17, 1932, 47 Stat. 2506.

56. Presidents Truman and Eisenhower expanded the Great Sand Dunes National Monument in 1946 and 1956, respectively. See Act of Mar. 12, 1946, 60 Stat. 1339; Act of June $7,1956,70$ Stat. c31. 
the Dunes depend.) Others who thought tourism would be promoted if the Great Sand Dunes were made a full-fledged national park joined these two interests. Secretary Babbitt and the Clinton Administration quickly endorsed the idea.

The question was how to handle the water issue in the designation process. Secretary Babbitt strongly supported an express reservation in the legislation of a traditional federal reserved water right for the expanded conservation area, defined to include the surface and groundwater resources that were necessary to protect the Dunes. The congressional delegation and local interests opposed a federal reserved right, largely on ideological and political grounds, because they did not want to be seen as promoting a full-scale takeover of the area's water resources. They argued for letting state water law control all aspects of the situation.

Our response, on behalf of the Interior Department, was that we didn't think state law was adequate to protect the federal interests, in two key respects. First, to the extent an instream flow water right would be required, state law would not allow the National Park Service to hold the right in its name. Only a state agency (the Colorado Water Conservation Board) could hold the right. ${ }^{57}$ This was unacceptable-if this was to be a national park, the water right necessary for its protection ought to be held in the name of, and controlled and enforceable by, the National Park Service. Second, we were concerned about how much substantive legal protection a Colorado state water right actually afforded to the surface and groundwater resources upon which the Dunes ecosystem depends.

While the initial discussions revealed a wide gap on the mechanism for getting there, clearly everyone shared the goal of expanding the federal land reservation, and securing adequate protection for its vital water resources. This agreement on the goal, and some flexibility on both sides, led in the end to an unusual and adroit marriage of state and federal law. The legislation Congress adopted last fall authorizes the federal government to secure a water right that will be appropriated, not reserved, through the processes of state law and in accordance with the priority system of state law. But, the right will be defined according to federal law-namely, whatever unappropriated surface and ground water is shown necessary for protection of the Dunes ecosystem-and the right will be held in the name of the Park Service. ${ }^{58}$ It is a new breed of federal water right-a federal non-reserved

57. See Colo. REv. STAT. § 37-92-102(3) (2000).

58. The legislation's key section, 9 (b) (2)(B), says the Secretary of the Interior is "specifically authorized to appropriate water under this Act exclusively for the purposes of maintaining ground water levels, surface water levels, and stream flows on, across, and under the national park and national preserve, in order to accomplish the purposes of the national park and the national preserve and to protect park resources and park uses." Great Sand Dunes National Park and Preserve Act of 2000, Pub. L. No. 106-530, $\S 9$ (b) (2) (B), 114 Stat. 2527, 2533-34. That this substantive standard of federal law preempts any inconsistent state law is made clear by an earlier part of section 9 (b)(2)(A), which says the water rights obtained and exercised by the 
right.

To water lawyers with memories that go back twenty-two years, those are very loaded words. I know, because I helped load them. As Associate Solicitor for Energy and Resources in the Carter Administration's Interior Department, I helped craft the infamous "Krulitz Opinion" "59 (named after Solicitor Leo Krulitz), which boldly announced that the federal government could claim a right to use water under the Federal Land Policy and Management Act of $1976^{60}$ ("FLPMA") without following the substance of state law. The reasoning was straightforward: FLPMA laid out a series of new management objectives for the BLM-managed public lands. Many of those objectives, such as wildlife habitat and ecosystem protection and some forms of recreation, required water, but the laws of many western states where public lands were located did not then acknowledge that water rights could be secured for such uses. Therefore, Solicitor Krulitz opined, if unappropriated water was available, the BLM could acquire a right to it using the procedures of state law, in accordance with the priority system of state law, but without conforming to the substance of state law. Instead, federal law-specifically, FLPMAwould define the substance of the right.

The opinion created a firestorm of protest that led the western governors to rise up en masse and persuade one of their former colleagues, then-Secretary of the Interior Cecil Andrus, to cease and desist. Within a year, Solicitor Krulitz had left and his successor, seasoned Colorado water lawyer and former professor Clyde Martz, rethought the matter. Martz issued a supplement to the Krulitz opinion saying Krulitz had it right in theory-there could be occasions where federal law could trump the substance of state water law where necessary to carry out federal programs-but wrong in application, because FLPMA did not contemplate that result. ${ }^{61}$ Krulitz had misread the statute, Martz said, in finding within it an intent to override state substantive water law.

There were more twists in the path to come. When the Reagan Administration took office, its Solicitor, William Coldiron, issued his own supplement to Martz's supplement to Krulitz's opinion. Coldiron said Krulitz and Martz were both wrong. Coldiron wrote that Congress could not-as a constitutional matter-ignore state substantive water law other than through a federal reserved water right. ${ }^{62}$ The federal "non-reserved" right, in other words, simply could not exist.

Finally, the Department of Justice weighed in, through Theodore

Secretary "to fulfill the purposes of the national park and the national preserve... shall be appropriated, adjudicated, changed, and administered pursuant to the procedural requirements and priority system of the laws of the State of Colorado." Id. \$ 9(b) (2) (A), 114 Stat. at 2533 (emphasis added).

59. See 86 Interior Decision 553, 614-618 (1979); see also SAX ET AL., supra note 1, at 872-73.

60. 43 U.S.C. $\$ \S 1701-1784$ (1994).

61. 88 Interior Decision 253 (1981).

62. 88 Interior Decision 1055, $1064-65$ (1981). 
Olson, the head of the Office of Legal Counsel. ${ }^{69}$ Olson's opinion, ${ }^{64}$ issued in 1982, is the modern equivalent of an Attorney General's opinion, the highest legal authority in the executive branch. Olson very gently chided Coldiron, ${ }^{65}$ saying he as well as Krulitz had got it wrong, and Martz was right. Congress has the constitutional power to create a non-reserved federal water right if its legislation made clear that's what it was doing (so Coldiron's suggestion to the contrary was wrong). But Congress had not done so in FLPMA (so on that point Krulitz was wrong and Martz was right). ${ }^{66}$ Olson's opinion is the last word on the subject; not having been disturbed since, it still expresses executive branch policy. Moreover, it seems clearly right on the issue of constitutional power, at least to this observer.

Nearly twenty years later, the Sand Dunes legislation gives Olson's view concrete realization. This legislation contains what may be the nation's first clear-cut example of a federal non-reserved water right, and a possible roadmap for how Congress might handle water issues in future federal land conservation designations.

\section{CoNCLUSION}

The Great Sand Dunes approach directly addresses most of the concerns that have arisen about the traditional way of handling water issues in new federal land conservation designations. It offers some distinct advantages over the alternatives of silence, an express federal reserved right, or total deference to state law. National interests are protected because the federal government holds an enforceable water right in its own name, and federal, not state law measures the substance of the right. This means the standard by which the right is quantified and adjudicated is one of federal law which, like the quantification and adjudication of a traditional federal reserved right,

63. Theodore Olson is known more recently for his work for President George W. Bush concerning the Florida election litigation. In late May 2001, the U.S. Senate confirmed Olson as Solicitor General of the United States.

64. Federal "Non-Reserved" Water Rights, 6 Op. Off. Legal Counsel 328 (1982).

65. Olson crafted his opinion to provide maximum comfort to the state water interests in the West while preserving federal supremacy. The opinion's opening paragraph sweepingly announces that the "federal non-reserved water rights theory which we address in this opinion does not provide an appropriate legal basis for assertion of water rights by federal agencies in the western states," $i d$. at 329, but the bulk of the opinion carefully and persuasively explains its conclusion that Congress has "ample power" to supersede state water law in particular cases without asserting a federal reserved water right. Id. at 383 . Similarly, while Olson's opinion criticizes the Krulitz Opinion at length, it never directly rebukes Solicitor Coldiron's opinion, although its conclusion is plainly at odds with Coldiron's. Compare id. at 361 with id. at 374-83.

66. See, e.g., id. at $357,361-62,383$.

67. I addressed the background of the Great Sand Dunes legislation and how its water rights provisions should be implemented in somewhat more detail in a legal opinion I signed, and in which Secretary Babbitt concurred, on January 18, 2001. Memorandum from the Office of the Solicitor, to the Director of the National Park Service (Jan. 18, 2001) (on file with the University of Denver, College of Law, Water Law Review). 
is ultimately reviewable by the Supreme Court of the United States. ${ }^{68}$

State interests are protected because the federal agency has to file for the right and, thus, the right may be adjudicated and administered in the state water administration system, and in accordance with the state priority system. Both sides are served by the fact that the uncertainty over the contours of the right may be resolved relatively promptly, without the need to wait decades for a general stream adjudication. And, more subtly, both sides are served because this approach compels them to cooperate more closely, which may foster better communications between, and more confidence in, each other.

This is not to say that questions won't arise about the contours of the Great Sand Dunes water right as Congress implements the statute. Gray areas will inevitably emerge when one tries to distinguish between process (governed by state law) and substance (governed by federal law). But problems of this kind exist today, when federal reserved rights are adjudicated and administered in state systems under the McCarran Amendment. ${ }^{69}$

All told, where proposed new federal land conservation designations are stalemated by a concern over what to say or not to say about water rights, the Great Sand Dunes approach may offer a way to break the impasse that accommodates the legitimate interests of both the federal and state governments. ${ }^{70}$ It deserves a serious look.

68. See, e.g., Arizona v. San Carlos Apache Tribe, 463 U.S. 545, 571 (1983).

69. See, e.g., SAX ET AL., supra note 1, at 825-29.

70. One might well ask, if this is such a good approach, why didn't the Clinton Administration take it in designating new national monuments? As noted in the text accompanying notes 24-37 supra, most of the recent national monuments specifically addressed water, but none took the non-reserved right approach. For one thing, we thought the idea would be controversial, given its relative novelty, and its association with the Krulitz/Martz/Coldiron opinions of a generation earlier. We were concerned that a controversy could undermine the larger land conservation objectives at stake in the monument designation process. It is also not completely clear that Congress had given the President the authority in the Antiquities Act to create a nonreserved right- to appropriate water through a state water right system but under federal substantive law. Although the Office of Legal Counsel ("OLC") rejected Solicitor Coldiron's view (see supra text accompanying note 62) that Congress could not give the Executive this power (see supra text accompanying notes 63-66), OLC left open the question whether, in individual statutes, Congress has done so. Perhaps, then, the Antiquities Act fails to give the Executive such authority, even though it seems ironic to argue that, while the Act implicitly gave the President authority to reserve water under the Winters doctrine (see supra text accompanying notes 13-15 (Cappaert discussion)), it did not at the same time implicitly authorize the Executive to preempt state water law in a considerably more limited way. The bottom line for the Administration was that the issues were too subtle, and the context too sensitive, to embark on a new approach as part of the national monuments initiative. While we thought the approach had merit, we believed it preferable to work through a test case, as it were, in bipartisan discussions with Congress in the context of the Sand Dunes legislation. 